\title{
MANAJEMEN BEBAN DENGAN PENDEKATAN TERAPI KELUARGA TRIANGLES DALAM MENGATASI BEBAN SUBJEKTIF KELUARGA MERAWAT KLIEN DIABETES MELITUS
}

\author{
Surya Efendi*, Herni Susanti, Ice Yulia Wardani, Angelina Roida Eka \\ Departemen Keperawatan Jiwa, Fakultas Ilmu Keperawatan, Universitas Indonesia, Pondok Cina, Kecamatan Beji, \\ Kota Depok, Jawa Barat, Indonesia 16424 \\ *suryaefendi3419@gmail.com
}

\begin{abstract}
ABSTRAK
Diabetes Melitus atau DM merupakan penyakit metabolik dengan angka kejadian yang mengalami peningkatan setiap tahunnya baik di dunia maupun di Indonesia. DM dapat memberikan dampak kepada penderita dan keluarga yang merawat. Dampak yang dialami keluarga dalam merawat penderita DM adalah meningkatnya beban keluarga yang akan berpengaruh terhadap kualitas perawatan kepada klien. Tujuan laporan kasus ini adalah untuk melakukan analisis lebih lanjut mengenai penerapan manajemen beban dengan pendekatan terapi keluarga triangles dalam mengatasi beban subjektif keluarga merawat klien DM. Metode yang digunakan dalam karya ilmiah ini adalah laporan kasus. Intervensi dilakukan terhadap satu keluarga penderita DM. Beban subjektif keluarga dinilai melalui pengamatan dan wawancara setelah intervensi dilaksanakan. Hasil yang didapatkan adalah beban subjektif keluarga, yaitu sedih dan kesal akibat kesalahpahaman antara klien dan keluarga dapat teratasi setelah dilakukan manajemen beban dengan pendekatan terapi keluarga triangles.
\end{abstract}

Kata kunci: diabetes mellitus, manajemen beban, psikoedukasi keluarga, terapi keluarga triangles

\section{BURDEN MANAGEMENT WITH TRIANGLES FAMILY THERAPY APPROACH IN OVERCOMING SUBJECTIVE FAMILY BURDEN THREATING THE CLIENTS OF DIABETES MELITUS}

\begin{abstract}
Diabetes Mellitus or DM is a metabolic disease with an increasing incidence every year. DM affects patients and families who care of them. The impact experienced by the family in treating patients with DM is increased family burden which will affect the quality of client care. The purpose of this study is to conduct further analysis of family burden management with triangles therapy approach in overcoming subjective burden of caring clients with DM. The method used in this study is a case report. This study was conducted on a family of DM patients. The subjective burden of the family was assessed through observation and interviews after the intervention is carried out. The results were the subjective family burden, that was sad and upset due to misunderstanding between client and family can be resolved after burden management with family triangles therapy approach was done.
\end{abstract}

Keywords: burden management, diabetes mellitus, family psychoeducation, family triangles therapy

\section{PENDAHULUAN}

Diabetes Melitus (DM) merupakan penyakit metabolik kronik dengan karakteristik peningkatan kadar glukosa dalam darah yang menyebabkan kerusakan serius pada jantung, pembuluh darah, mata, ginjal, dan saraf (World Health Organization, 2019). Angka kejadian penyakit DM di dunia pada tahun 2015 sekitar 415 juta orang dan diperkirakan akan mengalami peningkatan menjadi 642 juta orang pada tahun 2040. Sebesar $80 \%$ penderita DM tinggal di negara berpenghasilan rendah dan menengah (International Diabetes Federation, 2019). Angka penderita DM di Indonesia juga mengalami peningkatan, pada tahun 2013 sebanyak 1,5\% dan meningkat menjadi $2 \%$ dari jumlah penduduk Indonesia pada tahun 2018 (Kementerian Kesehatan RI, 2018).

Penyakit Diabetes Melitus (DM) menimbulkan berbagai dampak bagi penderitanya dan keluarga. DM yang tidak dikelola dengan baik akan menyebabkan terjadinya penyulit menahun, seperti jantung koroner, penyakit ginjal, penyakit pada serebrovaskuler, gangguan pembuluh darah dan tungkai, gangguan pada mata, stroke, ganggren, kelemahan fisik, kesemutan, berat badan menurun, neuropati, dan amputasi (Price \& Wilson, 2012; Waspadji, 2009). Dampak yang dialami oleh keluarga adalah meningkatnya beban 
keluarga. Merawat anggota dengan penyakit kronis menimbulkan beban bagi anggota keluarga yang lain. Beban yang dialami keluarga berkaitan dengan perasaan cemas dan stres akan masa depan keluarga, beban ekonomi karena komplikasi akut dan kronis membutuhkan biaya pengobatan yang dan perawatan yang banyak dan jangka waktu yang lama (Fontaine, 2009).

Hasil penelitian membuktikan bahwa merawat klien dengan penyakit fisik dapat meningkatkan beban waktu bagi keluarga (Rose et al., 2019). Penelitian lain membuktikan bahwa $31 \%$ caregiver yang merawat anak yang menderita mucopolysaccharidosis mengurangi jam kerja mereka dalam 6 bulan terakhir, dan $81 \%$ caregiver mengatakan kesulitan dalam melakukan pekerjaan karena merawat anak mereka (Conner, Cook, Fernandez, \& Rangel-Miller, 2019). Penelitian lain juga menunjukkan bahwa keluarga yang merawat klien yang mengalami cedera tulang belakang mengalami intensitas beban yang berbeda-beda, 52\% keluarga mengalami beban dengan kategori ringan sampai sedang, $43 \%$ keluarga mengalami beban dengan kategori sedang sampai berat, dan 5\% keluarga mengalami beban yang berat (Castellano-Tejedor \& LusillaPalacios, 2017). Penelitian lain membuktikan bahwa merawat klien dengan kanker paru-paru dapat meningkatkan beban keluarga (Hu, Peng, $\mathrm{Su}$, \& Huang, 2018). Beban yang dialami keluarga dapat mempengaruhi kualitas perawatan terhadap klien.

Tindakan keperawatan yang dapat diberikan kepada keluarga dalam mengurangi beban keluarga merawat klien adalah psikoedukasi keluarga. Hal ini didukung oleh penelitian yang menyebutkan psikoedukasi keluarga mampu mengurangi beban keluarga dalam merawat klien diabetes melitus (Isworo, Suharsono, \& Sitepu, 2019). Penelitian lain juga menyebutkan bahwa beban keluarga dalam merawat anggota keluarga yang sakit berkurang setelah diberikan psikoedukasi keluarga (Wulandari, Soeharto, \& Setyoadi, 2016). Penelitian lain juga menunjukkan hasil yang positif walaupun tidak berkaitan dengan beban keluarga, seperti penelitian yang dilakukan oleh Qolina, Hamid, \& Wardani (2017) yang membuktikan bahwa psikoedukasi keluarga dapat mengurangi ansietas keluarga. Penelitian lain juga menyatakan bahwa psikoedukasi keluarga mampu mengurangi gejala post traumatic stress disorder (Mughairbi, Abdulaziz Alnajjar, \& Hamid, 2019). Penelitian lain menyebutkan bahwa terapi psikoedukasi keluarga secara signifikan mampu menurunkan tingkat ansietas (Sianturi, Keliat dan Susanti, 2016).

Selain psikoedukasi keluarga terdapat tindakan keperawatan lainnya yaitu terapi keluarga triangles. Triangulasi merupakan cara untuk mengatasi kecemasan dalam hubungan keluarga (Gale \& Muruthi, 2017). Terapi keluarga triangles bertujuan untuk meningkatkan kemampuan diri dengan tetap mempertahankan hubungan keluarga. Masalah emosional yang terjadi pada keluarga inti dapat diselesaikan melalui hubungan yang tidak membeda-bedakan anggota keluarga. Penekanannya adalah dengan memberikan pemahaman mengenai hubungan mereka terhadap keluarga (Bowen, 1978). Penelitian membuktikan bahwa terapi keluarga triangles dapat mengurangi reaksi emosional keluarga (Messina, Kolbert, Bundick, Crothers, \& Strano, 2018).

Penulis melakukan intervensi keperawatan pada satu keluarga yang salah satu anggota keluarganya menderita diabetes melitus di Kp Kukupu RT 003 RW 005 Kelurahan Cibadak Kecamatan Tanah Sareal Kota Bogor. Keluarga mengalami beban dalam merawat klien khususnya beban subjektif, yaitu sedih dan kesal dikarenakan klien yang susah diingatkan untuk minum obat dan menghindari pantangan, serta adanya kesalahpahaman yang sering terjadi antara klien dan keluarga. Penyelesaian kesalahpahaman antar anggota keluarga membutuhkan keterlibatan semua anggota keluarga termasuk klien itu sendiri. Manajemen beban dengan pendekatan terapi keluarga triangles merupakan terapi yang tepat untuk mengatasi beban subjektif keluarga dengan melibatkan klien dan keluarga dalam intervensi. Belum pernah dilakukan sebelumnya manajemen beban dengan pendekatatan terapi keluarga triangles untuk mengatasi beban subjektif keluarga.

Latar belakang yang telah diuraikan tersebut menjadi dasar bagi penulis untuk melakukan analisis lebih lanjut mengenai manajemen beban keluarga dengan pendekatan terapi keluarga triangles dalam mengurangi beban subjektif keluarga merawat klien Diabetes Melitus di Kp Kukupu RT 003 RW 005 Kelurahan Cibadak Kecamatan Tanah Sareal Kota Bogor. Tujuan penulisan laporan kasus ini adalah untuk melakukan analisis lebih lanjut mengenai penerapan manajemen beban dengan pendekatan terapi keluarga triangles dalam mengatasi beban subjektif keluarga merawat klien DM. 


\section{METODE}

Desain yang digunakan dalam tulisan ini adalah laporan kasus. Intervensi dilakukan di Kp Kukupu RT 003 RW 005 Kelurahan Cibadak Kecamatan Tanah Sareal Kota Bogor mulai tanggal 1 November 2019 sampai dengan 22 November 2019 selama empat kali pertemuan. Intervensi dilakukan terhadap $\mathrm{Ny}$. A dan $\mathrm{Ny}$. R yang merupakan anak dari $\mathrm{Ny}$. $\mathrm{N}$ dan berperan sebagai caregiver dalam merawat $\mathrm{Ny}$. $\mathrm{N}$ yang menderita Diabetes Melitus. Penulis akan melihat penerapan manajemen beban yang merupakan bagian dari psikoedukasi keluarga dengan menggunakan pendekatan terapi keluarga triangles dalam mengatasi beban subjektif keluarga merawat $\mathrm{Ny}$. N. Beban subjektif keluarga dinilai melalui pengamatan dan wawancara setelah intervensi dilaksanakan. Penulis menggunakan buku kerja dan buku evaluasi terapi psikoedukasi keluarga untuk mencatat beban subjektif keluarga.

\section{HASIL}

Hasil pengkajian yang dilakukan pada tanggal 1 November 2019 diperoleh data sebagai berikut: klien Ny. N, 54 tahun, jenis kelamin perempuan, status perkawinan menikah, dan suku minang. Saat dilakukan pengkajian diperoleh data: klien menderita Diabetes Melitus (DM) sejak 6 tahun yang lalu, pernah dirawat dengan masalah DM bulan Agustus 2018 (GDS > 500 mg/dl). Keluhan saat ini adalah cemas dan nyeri pada kaki. Klien memiliki riwayat suka makan makanan yang manis, berminyak, dan bersantan, ibu klien memiliki riwayat kolesterol tinggi dan penyakit rematik. Saat ini klien sudah tidak bekerja lagi, pendidikan SD, orang terdekat di rumah adalah anak paling kecil, klien mengaku sering bertengkar dengan anaknya. hubungan dengan masyarakat baik, namun sejak sakit klien jarang ikut kegiatan di masyarakat.

Pengkajian pada keluarga diperoleh data: caregiver klien adalah kedua anaknya yang tinggal serumah dengan klien, suami klien bekerja di luar kota dan pulang setiap 2 minggu. Anak pertama bernama $\mathrm{Ny}$. A umur 32 tahun dan mempunyai 2 orang anak balita. Anak kedua bernama Ny. R umur 22 tahun dan mempunyai 1 orang anak balita dan 1 orang bayi berusia 7 bulan. Ny. A bekerja sebagai wiraswasta sedangkan Ny. $\mathrm{R}$ tidak bekerja. Keluarga mengatakan stres dan pusing karena ibunya susah diberi nasehat untuk menghindari pantangan dan minum obat secara teratur. Setiap diberi nasehat ibunya selalu mengatakan biar saja karena dirinya yang akan mengalami risikonya. Keluarga mengatakan ibunya sering salah paham dan sering mengatakan anaknya tidak tulus dalam merawat dirinya karena sering bicara dengan keras saat mengingatkan minum obat dan menghindari pantangan. Padahal keluarga mengatakan sebenarnya sangat tulus merawat ibunya. Keluarga juga mengatakan ibunya sering membeda-bedakan anaknya dimana ibunya sering membangga-banggakan anaknya yang tidak tinggal serumah dengannya karena selalu memberikan uang setiap bulan kepadanya dan tidak menghargai perawatan dan tempat tinggal yang sudah disediakan oleh anaknya. Hal ini membuat keluarga merasa sedih dan kesal sehingga sering bertengkar dengan ibunya. Keluarga juga megatakan tidak bisa optimal dalam merawat ibunya karena sibuk bekerja dan memiliki anak yang masih kecil. Keluarga juga mengatakan tidak tahu cara merawat dengan baik penyakit diabetes melitus yang dialami ibunya. Berdasarkan hasil pengkajian dan analisis data didapatkan diagnosis keperawatan keluarga adalah ketidakefektifan koping keluarga.

Tindakan keperawatan kepada keluarga berupa psikoedukasi keluarga. Tindakan yang diberikan dibagi menjadi 6 sesi berdasarkan modul psikoedukasi keluarga yang dikembangkan Departemen Keperawatan Jiwa Fakultas Ilmu Keperawatan Universitas Indonesia tahun 2019. Sesi 1: mengidentifikasi masalah kesehatan yang dihadapi dalam merawat klien dan merawat satu masalah kesehatan klien, sesi 2: merawat masalah kesehatan kedua dari klien, sesi 3: manajemen stres keluarga, sesi 4: manajemen beban keluarga, sesi 5: memanfaatkan sistem pendukung, dan sesi 6: mengevaluasi manfaat psikoedukasi keluarga. Pada sesi manajemen beban penulis menggunakan pendekatan terapi keluarga traingles.

Implementasi keperawatan pertama diberikan kepada Ny. A dan Ny. R pada tanggal 1 November 2019. Implementasi dilaksanakan selama 45 menit. Data subjektif yaitu keluarga mengatakan tidak tahu cara merawat penyakit diabetes melitus dan mengatasi cemas dan nyeri yang dirasakan oleh klien, keluarga mengatakan stres dan pusing karena klien susah dinasehati untuk menghindari pantangan dan minum obat kadang-kadang mereka sampai bertengkar, keluarga juga mengatakan klien sering salah paham terhadap keluarga dengan mengatakan anaknya tidak tulus dalam merawatnya, keluarga mengeluh sibuk bekerja dan punya anak yang masih kecil sehingga tidak maksimal dalam merawat klien. Data objektif yaitu keluarga sering bertanya tentang cara perawatan klien yang benar. 
Diagnosis keperawatan yaitu ketidakefektifan koping keluarga. Implementasi keperawatan yang dilakukan yaitu psikoedukasi keluarga sesi 1: identifikasi masalah kesehatan klien dan keluarga, dan latihan merawat masalah kesehatan klien (diabetes melitus dan ansietas).

Hasil implementasi pertemuan pertama adalah: evaluasi subjektif yaitu keluarga mengatakan masalah kesehatan klien adalah cemas dan kadang-kadang merasa nyeri pada kaki terutama saat malam hari. Masalah kesehatan keluarga adalah stress, pusing, sedih, dan kesal. Evaluasi objektif yaitu keluarga mampu mempraktikkan cara merawat diabetes melitus dan ansietas. Rencana tindak lanjut yaitu mempraktikkan merawat diabetes melitus dan ansietas secara mandiri.

Implementasi keperawatan pertemuan kedua diberikan kepada Ny. A dan Ny. R pada tanggal 8 November 2019. Implementasi dilaksanakan selama 45 menit. Data subjektif yaitu keluarga mengatakan sudah mempraktikkan merawat kecemasan yang dialami klien, keluarga belum tahu cara merawat nyeri pada kaki klien, keluarga merasa stres dan pusing karena klien susah dinasehati untuk menghindari pantangan dan minum obat kadang-kadang mereka sampai bertengkar. Data objektif yaitu keluarga sering bertanya tentang cara mengatasi nyeri pada kaki klien, dan tampak tegang. Diagnosis keperawatan yaitu ketidakefektifan koping keluarga. Implementasi keperawatan yang dilakukan yaitu psikoedukasi keluarga sesi 2: latihan merawat masalah kesehatan klien kedua (nyeri), dan psikoedukasi keluarga sesi 3: manajemen stres keluarga (relaksasi dan hipnotis 5 jari).

Hasil implementasi pertemuan kedua adalah: evaluasi subjektif yaitu keluarga mengatakan sudah memahami cara merawat masalah nyeri pada klien, keluarga mengatakan merasa lega setelah mempraktekkan latihan relaksasi (tarik nafas dalam) dan hipnotis 5 jari. Evaluasi objektif yaitu keluarga mampu mempraktikkan cara merawat masalah nyeri pada klien, latihan relaksasi, dan hipnotis 5 jari. Rencana tindak lanjut yaitu mempraktikkan latihan merawat nyeri dan latihan manajemen stres secara mandiri.

Implementasi keperawatan pertemuan ketiga diberikan kepada $\mathrm{Ny}$. A dan $\mathrm{Ny}$. R pada tanggal 15 November 2019. Implementasi dilaksanakan selama 45 menit. Data subjektif yaitu keluarga mengatakan tidak bisa merawat klien secara optimal karena sibuk bekerja dan punya anak yang masih kecil, keluarga juga mengatakan klien sering salah paham pada keluarga sehingga keluarga merasa sedih dan kesal. Data objektif yaitu keluarga tampak antusias menyebutkan beban yang mereka rasakan selama merawat klien. Diagnosis keperawatan yaitu ketidakefektifan koping keluarga. Implementasi keperawatan yang dilakukan yaitu psikoedukasi keluarga sesi 4: manajemen beban keluarga. Pada sesi ini juga dilakukan terapi keluarga triangles untuk membantu menyelesaikan kesalahpahaman antara klien dan keluarga. Pertama perawat berdiskusi dengan anggota keluarga terkait kesalahpahaman yang terjadi, kemudian keluarga diberikan kesempatan untuk menyampaikan persepsi terhadap masalah dan pandangan mereka terhadap penyelesaian masalah serta harapan keluarga terhadap masalah yang terjadi. Selanjutnya hal yang sama dilakukan pada klien. Setelah perawat bertemu dengan klien dan keluarga di tempat yang terpisah, klien dan keluarga bersepakat untuk bertemu dan menyelesaikan kesalahpahaman diantara mereka agar tidak lagi bertengkar.

Hasil implementasi keperawatan pertemuan ketiga adalah: evaluasi subjektif yaitu keluarga mengatakan akan mencoba berbagi peran dalam merawat klien, dan melakukan diskusi keluarga untuk mengatasi kesalahpahaman antara keluarga dengan klien. Data objektif yaitu keluarga tampak antusias saat berdiskusi untuk mengatasi beban keluarga. Rencana tindak lanjut yaitu mempraktikkan berbagi peran dalam merawat klien secara mandiri, dan melakukan diskusi keluarga untuk mengatasi kesalahpahaman antara keluarga dengan klien.

Implementasi keperawatan pertemuan keempat diberikan kepada $\mathrm{Ny}$. A dan $\mathrm{Ny}$. R pada tanggal 22 November 2019. Implementasi dilaksanakan selama 45 menit. Data subjektif yaitu keluarga mengatakan tidak tahu cara memanfaatkan sistem pendukung yang ada di luar keluarga. Diagnosa keperawatan adalah ketidakefektifan koping keluarga. Implementasi keperawatan yang dilakukan adalah psikoedukasi keluarga sesi 5: memanfaatkan sistem pendukung, sesi 6: mengevaluasi manfaat psikoedukasi keluarga. Pada sesi ini juga dilanjutkan terapi keluarga triangles yaitu mempertemukan klien dengan keluarga untuk menyelesaikan kesalahpahaman. Keluarga diberikan kesempatan untuk menyampaikan perasaan dan hambatan yang dirasakan dalam merawat klien. Klien juga diberikan kesempatan untuk menyampaikan perasaannya selama dirawat oleh anaknya. 
Kemudian dilanjutkan dengan diskusi untuk mencari persamaan pandangan antar anggota keluarga serta harapan yang ingin dicapai kedepannya.

Hasil implementasi keperawatan pertemuan keempat adalah: evaluasi subjektif yaitu keluarga mengatakan sistem pendukung yang bisa dimanfaatkan adalah kader kesehatan, tetangga, dan puskesmas. Keluarga mengatakan terapi yang diberikan bermanfaat dalam meningkatkan kemampuan keluarga merawat ibunya, mengurangi stres dan beban yang mereka rasakan dalam merawat, serta mampu mengatasi kesalahpahaman diantara keluarga dengan ibunya. Evaluasi objektif yaitu klien dan keluarga tampak sepakat untuk mengakhiri kesalahpahaman dan mencoba untuk saling mengerti dan memahami satu sama lain. Keluarga sepakat akan memberi nasehat kepada ibunya dengan cara yang baik dan sopan. Klien juga sepakat tidak akan membedabedakan anaknya dan menyadari bahwa yang dilakukan oleh anaknya adalah yang terbaik demi kesembuhannya.

\section{PEMBAHASAN}

Keluarga memiliki peran yang sangat penting dalam proses perawatan klien. Friedman et al (2014) mengatakan bahwa dukungan keluarga merupakan sikap, tindakan, dan keputusan keluarga terhadap anggota keluarga yang sakit. Anggota keluarga yang sakit akan merasa senang dan tentram dengan adanya dukungan dari keluarga, sehingga akan meningkatkan kepercayaan dirinya dalam menghadapi dan mengelola penyakitnya. Routh, Hurt, Winham, \& Lanningham-Foster (2019) menyebutkan bahwa anggota keluarga memiliki keterkaitan dan ketergantungan yang mempengaruhi anggota keluarga yang lain dalam sistem keluarga. Interaksi dan komunikasi keluarga berpengaruh terhadap pencegahan dan implikasi kesehatan klien Diabetes Melitus. Selain itu keluarga juga berperan dalam memberikan dukungan emosional kepada anggota keluarga yang sakit (Varcarolis, 2013). Hal ini didukung oleh penelitian Peleg, Hadar, \& Cohen (2019) yang menyebutkan bahwa bahwa gaya hidup yang tepat, pengurangan stres, dan dukungan keluarga merupakan strategi utama mengatasi penyakit yang dialami oleh anggota keluarga. Pendapat lain menyatakan bahwa ketidakmampuan keluarga menjalankan fungsi keluarga dapat menjadi faktor penyebab ketidakmampuan keluarga merawat anggota keluarga yang sakit (Nancye, 2015).
Tindakan keperawatan yang diberikan pada kasus untuk meningkatkan dukungan dan kemampuan keluarga dalam merawat klien, serta mengurangi beban dan stres yang dialami keluarga adalah psikoedukasi keluarga. Menurut Townsend (2014) psikoedukasi keluarga merupakan bentuk dari terapi modalitas yang berfokus pada keluarga. Keluarga dibantu untuk mengenal dan menemukan pemecahan masalah terhadap kondisi maladaptif baik terhadap diri sendiri maupun berhubungan dengan orang lain. Shives (2012) menambahkan bahwa tujuan psikoedukasi keluarga adalah membawa dampak yang positif terhadap anggota keluarga.

Psikoedukasi keluarga yang diberikan pada kasus mampu meningkatkan pengetahuan dan kemampuan keluarga dalam merawat klien, meningkatkan kemampuan keluarga mengelola stres, dan mengatasi beban dalam merawat klien. Hal ini sejalan dengan hasil penelitian yang membuktikan bahwa keluarga yang merawat lansia mengalami penurunan beban setelah diberikan psikoedukasi keluarga (Boyacıoğlu \& Kutlu, 2017). Penelitian lain juga menyebutkan bahwa psikoedukasi keluarga mampu mengurangi beban keluarga dalam merawat klien diabetes melitus (Isworo et al., 2019). Penelitian lain juga menunjukkan hasil yang sama dimana kecemasan dan persepsi beban keluarga menurun setelah diberikan psikoedukasi keluarga (Rosmaharani, Wihastuti, \& Supriati, 2015). Penelitian pada klien skizofrenia menunjukkan bahwa psikoedukasi keluarga mampu meningkatkan pengetahuan keluarga, mengurangi gejala, mengurangi beban keluarga, meningkatkan kualitas hidup klien dan keluarga, serta mengurangi tingkat kekambuhan (Harvey, 2018; Hasan, Callaghan, \& Lymn, 2015; Liza, Loebis, \& Camellia, 2019).

Manajemen beban merupakan bagian dari psikoedukasi keluarga yaitu tepatnya pada sesi keempat. Penulis menggunakan pendekatan terapi keluarga triangles dalam mengaplikasikan manajemen beban keluarga. Pada kasus diketahui bahwa keluarga memiliki beban subjektif dan beban objektif yang berpengaruh terhadap perawatan klien. Menurut Stuart et al (2016) beban subjektif adalah perasaan memiliki beban pada seseorang yang bersifat individual. Sedangkan beban objektif adalah beban yang berkaitan dengan penampilan peran, perilaku klien, dampak buruk yang dialami keluarga, kebutuhan dukungan, ataupun biaya finansial dari penyakit yang diderita. 
Psikoedukasi keluarga sesi 4: manajemen beban yang penulis lakukan adalah mengidentifikasi beban subjektif dan beban objektif yang dialami keluarga selama merawat klien. Kemudian dilanjutkan dengan mendiskusikan cara mengatasi beban. Berdasarkan pengkajian diperoleh data bahwa beban objektif yang dirasakan keluarga selama merawat klien adalah beban waktu dan tenaga, sedangkan beban subjektif keluarga adalah sedih dan kesal dalam menghadapi sikap klien serta karena adanya kesalahpahaman antara klien dan keluarga. Beban waktu dan tenaga dapat teratasi dengan teknik pembagian peran dalam merawat klien. Namun, beban psikologis dan kesalahpahaman antara keluarga dan klien memerlukan pendekatan yang berbeda agar bisa teratasi dengan baik.

Penyelesaian kesalahpahaman tidak bisa hanya sekedar dilakukan terhadap keluarga saja namun memerlukan adanya keterlibatan klien. Pendekatan yang bisa digunakan adalah dengan melibatkan klien dan keluarga secara langsung dengan terapis berperan sebagai supervisor. Bowen (1978) menerangkan bahwa terapi keluarga triangles mengutamakan keterampilan dan kerja sama yang bertujuan untuk menyelesaikan masalah yang dihadapi keluarga dengan melibatkan terapis, klien dan keluarga. Menurut Gale \& Muruthi (2017) triangulasi merupakan cara untuk mengatasi kecemasan dalam hubungan keluarga.

Manajemen beban keluarga dengan pendekatan terapi keluarga triangles menghasilkan kesepakatan bahwa keluarga akan melakukan diskusi keluarga untuk mengatasi kesalahpahaman. Diskusi antara klien dan keluarga difasilitasi oleh penulis dan dilaksanakan pada pertemuan keempat. Klien dan keluarga tampak sepakat untuk mengakhiri kesalahpahaman dan mencoba untuk saling mengerti dan memahami satu sama lain. Keluarga sepakat akan memberi nasehat kepada ibunya dengan cara yang baik dan sopan. Klien juga sepakat tidak akan membeda-bedakan anaknya dan menyadari bahwa yang dilakukan oleh anaknya adalah yang terbaik demi kesembuhannya. Klien dan keluarga mengatakan terapi yang diberikan oleh penulis bermanfaat dalam membantu mengatasi masalah klien dan keluarga. Hal ini menunjukkan bahwa manajemen beban dengan pendekatan terapi keluarga triangles terbukti mampu mengatasi beban subjektif keluarga yang pada akhirnya diharapkan perawatan klien diabetes melitus oleh keluarga dapat lebih optimal.
Keberhasilan intervensi yang penulis lakukan dalam mengatasi beban subjektif keluarga dipengaruhi oleh beberapa hal, diantaranya adalah hubungan saling percaya yang terbina dengan baik sejak awal pertemuan, dan penulis menggunakan bahasa minang saat pemberian intervensi. Menurut Potter \& Perry (2009) membina hubungan saling percaya merupakan kemampuan perawat dalam memelihara dan membangun komunikasi interpersonal yang baik. Hubungan perawat dan klien membutuhkan kebersamaan dan rasa saling percaya agar tujuan tindakan keperawatan dapat tercapai. Stuart (2009) menambahkan bahwa komunikasi yang menciptakan tumbuhnya hubungan saling percaya (trust) harus dicapai terlebih dahulu sebelum menggali permasalahan dan memberikan alternatif pemecahan masalah.

Penggunaan bahasa yang sesuai dengan latar belakang budaya klien juga merupakan faktor penting dalam keberhasilan tindakan keperawatan. Penulis menggunakan bahasa minang dalam memberikan tindakan keperawatan karena klien dan keluarga merupakan suku minang. Penggunaan bahasa minang dapat menciptakan kedekatan interpersonal antara penulis dengan klien dan keluarga sehingga klien dan keluarga lebih terbuka dan menerima penulis dengan baik. penggunaan bahasa minang juga membuat klien dan keluarga lebih mudah memahami intervensi yang diberikan. Potter \& Perry (2009) menjelaskan bahwa bahasa dan gaya komunikasi akan sangat dipengaruhi oleh faktor budaya. Budaya juga akan membatasi cara bertindak dan berkomunikasi seseorang.

Hambatan dalam proses pemberian tindakan keperawatan yaitu keluarga memiliki anak yang masih kecil dan masih tergantung dengan orang tua. Hal ini mengakibatkan keluarga kadangkadang tidak fokus dalam mengikuti tindakan keperawatan. penulis mengantisipasi hal tersebut dengan melakukan kontrak waktu satu hari sebelum intervensi dan memberikan intervensi saat anak-anak dari keluarga klien tidur atau sedang bermain.

\section{SIMPULAN}

Pelaksanaan manajemen beban dengan pendekatan terapi keluarga triangles terbukti mampu membantu mengatasi beban subjektif yang dirasakan Ny. A dan Ny. R dalam merawat Ibunya yang menderita Diabetes Melitus. Hal ini ditandai dengan perasaan sedih dan kesal akibat 
sikap klien dan kesalahpahaman antara klien dan keluarga dapat diatasi setelah diberikan intervensi keperawatan.

\section{DAFTAR PUSTAKA}

Bowen, M. (1978). Family Therapy in Clinical Practice. New York: Jason Aronson.

Boyacıŏlu, N. E., \& Kutlu, Y. (2017). The Effectiveness of Psychoeducational Interventions in Reducing the Care Burden of Family Members Caring for the Elderly in Turkey: A Randomized Controlled Study. Archives of Psychiatric Nursing, 31(2), 183-189. https://doi.org/10.1016/j.apnu.2016.09.012

Castellano-Tejedor, C., \& Lusilla-Palacios, P. (2017). A study of burden of care and its correlates among family members supporting relatives and loved ones with traumatic spinal cord injuries. Clinical Rehabilitation, 31(7), 948-956. https://doi.org/10.1177/0269215517709330

Conner, T., Cook, F., Fernandez, V., \& RangelMiller, V. (2019). An online survey of burden of illness in families with mucopolysaccharidosis type II children in the United States. Molecular Genetics and Metabolism Reports, 21(January 2018), 100499.

https://doi.org/10.1016/j.ymgmr.2019.1004 99

Fontaine. (2009). Mental Health Nursing Care Plan (6th ed.). New Jersey: Perason Prentice hall.

Friedman, M. M., Bowden, V. R., \& Jones, E. G. (2014). Buku Ajar Keperawatan Keluarga: Riset, Teori \& Praktik (5th ed.). Jakarta: EGC.

Gale, J., \& Muruthi, B. (2017). Triangles and Triangulation in Family Systems Theory BT - Encyclopedia of Couple and Family Therapy. In J. Lebow, A. Chambers, \& D. C. Breunlin (Eds.) (pp. 1-3). Cham: Springer International Publishing. https://doi.org/10.1007/978-3-319-158778_758-1

Harvey, C. (2018). Family psychoeducation for people living with schizophrenia and their families, 24, 9-19. https://doi.org/10.1192/bja.2017.4
Hasan, A. A., Callaghan, P., \& Lymn, J. S. (2015). Evaluation of the impact of a psycho-educational intervention for people diagnosed with schizophrenia and their primary caregivers in Jordan : a randomized controlled trial, 1-10. https://doi.org/10.1186/s12888-015-0444-7

Hu, X., Peng, X., Su, Y., \& Huang, W. (2018). Caregiver burden among Chinese family caregivers of patients with lung cancer: A cross-sectional survey. European Journal of Oncology Nursing, 37(September), 74-80. https://doi.org/10.1016/j.ejon.2018.11.003

International Diabetes Federation. (2019). Diabetes Atlas. Retrieved December 11, 2019, from https://www.idf.org/aboutdiabetes/what-isdiabetes.html

Isworo, A., Suharsono, \& Sitepu, F. Y. (2019). The relationship between psychoeducation and the decrease in family burden of diabetes mellitus patients, Magelang, Indonesia. Indian Journal of Public Health Research and Development, 10(8), 1940$1944 . \quad$ https://doi.org/10.5958/09765506.2019 .02136 .3

Kementerian Kesehatan RI. (2018). Riset Kesehatan Dasar. Jakarta: Badan Penelitian dan Pengembangan Kesehatan.

Liza, R. G., Loebis, B., \& Camellia, V. (2019). Efektivitas intervensi psikoedukasi keluarga terhadap kekambuhan pasien skizofrenia, 42(3), $128-136$. https://doi.org/10.25077/mka.v42.i3.p128136.2019

Messina, K. C., Kolbert, J. B., Bundick, M. J., Crothers, L. M., \& Strano, D. A. (2018). The impact of counseling on Bowen's differentiation of self. Family Journal, 26(2), $150-155$. https://doi.org/10.1177/1066480718776197

Mughairbi, F. Al, Abdulaziz Alnajjar, A., \& Hamid, A. (2019). Effects of Psychoeducation and Stress Coping Techniques on Posttraumatic Stress Disorder Symptoms. Psychological Reports. https://doi.org/10.1177/0033294118825101

Nancye, P. M. (2015). Pengaruh terapi keluarga 
terhadap dukungan keluarga dalam merawat klien dengan masalah perilaku kekerasan di Kota Surabaya. S1 Keperawatan, (Vol 4, No 1 (2015): Keperawatan). Retrieved from http://ejournal.stikeswilliambooth.ac.id/inde x.php/S1Kep/article/view/54

Peleg, O., Hadar, E., \& Cohen, A. (2019). Individuals With Type 2 Diabetes: An Exploratory Study of Their Experience of Family Relationships and Coping With the Illness. Diabetes Educator, 1-11. https://doi.org/10.1177/0145721719888625

Potter, \& Perry. (2009). Fundamental of Nursing (7th ed.). Jakarta: Salemba Medika.

Price, S. A., \& Wilson, L. M. (2012). Patofisiologi: Konsep Klinis Proses-Proses Penyakit. Jakarta: EGC.

Qolina, E., Hamid, A. Y. S., \& Wardani, I. Y. (2017). Pengaruh Psikoedukasi Keluarga terhadap Ansietas dan Depresi Keluarga yang Mempunyai Anak dengan Autis di Sekolah Khusus Autis Harapan Utama Ananda Depok. Jurnal JKFT: Universitas Muhammadiyah Tanggerang, 2, Juli-De, 90-97.

Rose, A. M., Grosse, S. D., Garcia, S. P., Bach, J., Kleyn, M., Simon, N. E., ... States, U. (2019). The financial and time burden associated with phenylketonuria treatment in the United States. Molecular Genetics and Metabolism Reports, 21(October), 100523.

https://doi.org/10.1016/j.ymgmr.2019.1005 23

Rosmaharani, S., Wihastuti, T. A., \& Supriati, L. (2015). Pengaruh psikoedukasi keluarga terhadap perubahan tingkat kecemasan dan persepsi beban keluarga merawat anak dengan retardasi mental di SLB Negeri Kabupaten Jombang. The Indonesian Journal of Health Science, 5(2), 213-221.
Routh, B., Hurt, T., Winham, D., \& LanninghamFoster, L. (2019). Family Legacy of Diabetes-Related Behaviors: An Exploration of the Experiences of African American Parents and Adult Children. Global Qualitative Nursing Research, 6. https://doi.org/10.1177/23333393619852343

Shives, L. R. (2012). Basic Concepts of Psychiatri Mental Health Nursing (8th ed.). Florida: Lippincott Williams \& Wilkins.

Stuart, G. W. (2009). Principle and Practice of Psychiatric Nursing (9th ed.). St. Louis: Mosby Elsevier. Inc.

Stuart, G. W., Keliat, B. A., \& Pasaribu, J. (2016). Prinsip dan Praktik Keperawatan Kesehatan Jiwa Stuart. Singapore: Elsevier Ltd.

Townsend, M. C. (2014). Psychiatric Mental Health Nursing: Concept of Care in Evidence Based Practice (7th ed.). Philadelphia: F. A. davis company.

Varcarolis, E. M. (2013). Essentials of Psychiatric Mental Health Nursing (2nd ed.). China: Elsevier.

Waspadji, S. (2009). Penatalaksanaan Diabetes Melitus Terpadu Sebagai Panduan Penatalaksanaan Diabetes Bagi Dokter Maupun Edukator. Jakarta: Balai Penerbit FK UI.

World Health Organization. (2019). Diabetes. Retrieved December 28, 2019, from https://www.who.int/health-topics/diabetes

Wulandari, R. A., Soeharto, S., \& Setyoadi. (2016). Pengaruh Terapi Psikoedukasi Keluarga terhadap Harga Diri Rendah dan Beban Keluarga dengan Anak Retardasi Mental, 4(2) 